\title{
Лысунец М.В. \\ Приоритетные направления государственного стимулирования развития экономики стран ЕС
}

Московский Государственный Университет имени М.В. Ломоносова (Россия, Москва)

doi:10.18411/spc-8-03-2018-07

idsp: 000001:spc-8-03-2018-07

В Стратегии [1] развития Евросоюза до 2020 года обозначены основные направления, призванные способствовать экономическому подъему и развитию экономики региона, реализация которых также содействует решению текущих актуальных проблем и задач. Стратегия основана на концепции «умного, устойчивого и инклюзивного» развития, где «умное» предполагает развитие экономики, основанной на знаниях и инновациях, «устойчивое» означает конкурентоспособную, ресурсноэффективную, зеленую экономику, а «инклюзивное» предполагает социальноориентированную экономику, которая способствует росту занятости населения, экономической, социальной и территориальной сплоченности региона, при этом, все эти три составляющие концепции развития взаимно усиливают друг друга [2].

Стратегия развития предполагает проведение структурных реформ [3] в краткои среднесрочной перспективе, направленных на решение определенных экономических, социальных, политических и прочих задач и сфокусированных, главным образом, на следующем:

- Проведение эффективной социальной политики, направленной на регулирование рынка труда, социальную интеграцию, социальную безопасность, усовершенствование системы социального обеспечения, повышение уровня жизни населения,

- Разработка политики в отношении мигрантов и беженцев, защита и контроль границ региона,

- Разработка и применение грамотной политики бюджетирования и распределения бюджетных средств, управления государственным долгом,

- Корректировка государственной политики в отношении финансового сектора экономики,

- Институциональные реформы и создание эффективной системы государственного управления,

- Реформа системы правосудия, усиление антикоррупционных мероприятий,

- Улучшение делового климата, развитие негосударственного сектора, увеличение доступности финансирования для малого и среднего бизнеса,

- Стимулирование инвестиций, в том числе прямых иностранных инвестиций, развитие конкурентоспособности, усовершенствование системы государственных закупок,

- Дальнейшая поддержка, развитие и внедрение инноваций, достижение устойчивого роста различных секторов экономики,

- Поддержка и развитие сферы образования,

- Корректировка системы здравоохранения,

- Реформирование агропромышленного комплекса и развитие сельских районов,

- Решение вопросов экологической безопасности и глобального потепления.

Соответственно, основными задачами на ближайшую перспективу в ЕС в целом являются обеспечение достаточного уровня занятости населения, особенно среди 
молодежи, улучшение благосостояния граждан ЕC, развитие образования, стимулирование инвестиционной активности, развитие инноваций и научноисследовательских разработок. Кроме того, перед ЕС стоят вопросы сокращения дефицита государственного бюджета и размера государственного долга, усовершенствования энергетического сектора, защиты окружающей среды, структурных реформ в экономике.

В программных документах ЕC заявлено, что вопросам социальноэкономической политики отводится первостепенное значение. Проблемы занятости и благополучия региона стоят на первом месте в списке задач социальногоэкономического развития ЕС. Социальная справедливость и высокий уровень занятости населения являются одними из основных составляющих восстановления экономического роста и последующего подъема экономики. Более того, многие исследователи заявляют, что возможности дальнейшей конвергенции в ЕС будут напрямую зависеть от решения проблемы с созданием рабочих мест, усовершенствования рынка труда в ЕС, а также достижения достаточного уровня социальной защищенности граждан [4]. В настоящий момент уровень безработицы в ЕС остается на очень высоком уровне, несмотря на то, что он сократился в последнее время. Так, данным Евростата уровень безработицы в сентябре 2017 года зафиксирован на уровне $8.9 \%$ в еврозоне и 7.5\% по всему ЕС в целом [5].

Снижение уровня безработицы, как одной из первоочередных социальных задач, находит свое отражение и в проводимой налогово-бюджетной политике в странах ЕС. Ее задачи заключаются в расширении налоговых вычетов для детей, семей и индивидуальных предпринимателей, предоставление налоговых кредитов физическим лицам, снижение уровня социальных взносов для молодых работников или даже полное освобождение от их уплаты на первые несколько лет работы постоянных работников (призванное стимулировать работодателей нанимать более молодой персонал), и восполнение бюджетных поступлений по подоходному налогу за счет переноса основной нагрузки на высокооплачиваемые категории граждан, а также компенсация бюджетных поступлений за счет налогов на потребление, пересмотра налогов на недвижимость, экологических налогов, а также за счет сокращения расходования бюджетных средств.

Еще одним первостепенным направлениемразвития и обновления экономики ЕС является стимулирование инноваций и инвестицийв развитие научноисследовательских разработок (НИР). Активные меры государственного стимулирования инновационной активности в ЕС приходятся на период с начала кризиса до настоящего времени и направлены как на поощрение компаний осуществлять непосредственно расходы на НИР, так и на непосредственную коммерциализацию результатов проведенных НИР. Эти меры имели положительное влияние на стимулирование притока инвестиций в область НИР, хотя и не в том объеме, который ожидался на государственном уровне. Помимо увеличения осуществляемых расходов на НИР ожидается, что данные мероприятия будут стимулировать компании к производству новых инновационных продуктов (товаров и услуг), в том числе и отвечающих социальным потребностям общества.

Данному вопросу придается большое значение, как рычагу, который позволит дать существенный толчок экономическому и инновационному росту и развитию региона. В соответствии со стратегическим планом развития обозначена цель относительно расходов на инновации в 3\% от ВВП, которую ЕС поставил себе достичь к 2020 году [1, 6]. В абсолютном выражении эта величина должна составить 315 млрд.евро дополнительных инвестиций к концу 2017 года, 500 млрд.евро. к 2020 году, и 630 млрд.евро к 2022 году [6].

Для привлечения этих инвестиций при поддержке Европейского Парламента, Европейского Совета, а также Европейского Инвестиционного банка был создан 
Европейский фонд стратегических инвестиций, целью которого является мобилизации заявленных инвестиций с максимальным участием и привлечением частного капитала. Уже проводится финансирование инвестиционных проектов в реальном секторе экономики, в том числе и отдельных проектов малого и среднего бизнеса.

Описанные мероприятия являются приоритетными направлениями государственного стимулирования развития экономики стран ЕС на ближайшую перспективу и призваны содействовать экономическому подъему региона, способствовать выходу из экономической рецессии. В связи с этим необходимо создание новых рабочих мест и поддержания занятости, последовательное проведение эффективной социальной, налогово-бюджетной, экономической политик, отвечающих социальным и экономическим потребностям, а также стимулирование инновационных разработок.

$$
* * *
$$

1. Europe 2020. A Strategy for Smart, Sustainable and Inclusive Growth. Available at: http://eurlex.europa.eu/LexUriServ/LexUriServ.do?uri=COM:2010:2020:FIN:EN:PDF.

2. European Semester: Working for a Stronger and More Inclusive Economic Recovery, 16.11.2016. Available at: http://europa.eu/rapid/press-release_AC-16-3899_en.htm.

3. Structural Reform Support Programme for the Period $2 \overline{0} 17$ to $2020,26.11 .2015$. Available at: http://ec.europa.eu/europe2020/pdf/2016/ags2016_structural_reform_support_programme_en.pdf.

4. Annual Growth Survey 2016. Strengthening the Recovery and Fostering Convergence, 26 November 2015. Available at: http://ec.europa.eu/europe2020/pdf/2016/ags2016_annual_growth_survey.pdf.

5. European Semester Autumn Package: Striving for sustainable and inclusive growth, 22.11.2017. Available at: http://europa.eu/rapid/press-release_IP-17-4681_en.htm.

6. The Investment Plan for Europe / European Commission. - 2016. - 26 September 2016. Available at: https://ec.europa.eu/commission/sites/beta-political/files/2-years-on-investment-plan_en_0.pdf.

\section{Мызрова К.А., Козлова К.А. \\ Имидж руководителя как важный элемент организационной культуры организации}

Ульяновский государственный университет (Россия, Ульяновск)

doi:10.18411/spc-8-03-2018-08

idsp: 000001:spc-8-03-2018-08

\section{Аннотация}

В данной статье авторы анализируют понятия «имидж руководителя» и «имидж организации», его взаимосвязь с корпоративной культурой организации. Формирование корпоративной культуры и её изменение по большей части зависят именно от руководителя организации: от его ценностей, целей и задач.

Ключевые слова: имидж руководителя, имидж организации, организационная культура.

Одной из важнейших задач организационной культуры является задача обеспечения внутреннего единства и интеграции: она призвана регулировать решение работниками ежедневных проблем, связанных с работой и жизнью в организации. Любая вновь возникающая организация формирует свою культуру, которая определяет её место, внутренние и внешние отношения и является образцом, стереотипом при формировании стратегии, распределении власти, принятии решений, поведения персонала.

Особый интерес для маркетологов представляет то, каким образом организационная (корпоративная) культура может помочь компании привлечь и удержать потребителей, для акционеров важны последствия для капитализации компании, для инвесторов - возможность принять решение об участии в проекте. 